\title{
REPRODUCTIVE PERFORMANCE OF EGYPTIAN BUFFALO BULLS ADMINISTRATED WITH N-ACETYLCYSTEINE, L-CARNITINE, OR THEIR COMBINATION
}

\author{
H.A. El-Nagar ${ }^{1}$; M.E.R. Hammad ${ }^{2}$; A.R. Hemida ${ }^{2}$ and A.A. Gabr ${ }^{2}$ \\ ${ }^{1}$ Animal Production Research Institute, Agricultural Research Center, Giza, Egypt. \\ ${ }^{2}$ Animal Production Department, Faculty of Agriculture, Tanta University, Egypt. \\ *Corresponding Author's E-mail: elnagar1970@hotmail.com, Cellular phone +201066315955
}

(Received 12/5/2021, accepted 9/6/2021)

\section{SUMMERY}

$\mathrm{T}$ This study was to evaluate the effect of daily oral administration of N-acetylcysteine (NAC), Lcarnitine (L-C), or their Combination for 2 months pre-semen collection on semen quality, sexual desire and some blood parameters traits of Egyptian buffalo bulls. A total of 20 bulls (400 \pm 37 kg LBW and 24-25 mo old) were divide into 4 groups. In group1 (G1, control), G2, G3 and G4, animals fed a basal ration and the managed under the same conditions, and were received orally a daily dose of $0,3 \mathrm{~L}-\mathrm{C}, 3 \mathrm{~g} \mathrm{NAC}$, or $1.5 \mathrm{~g} \mathrm{NAC}+1.5 \mathrm{~g} \mathrm{~L}-\mathrm{C}$ as a combination/bull/day, respectively, for 2 months. The results showed that bulls that received the combination dose $(\mathrm{G} 4)$ increased $(\mathrm{P}<0.05)$ the concentration of total proteins, albumin, globulin and glucose, while it decreased $(\mathrm{P}<0.05)$ total cholesterol, triglyceride, creatinene concentrations, and AST and ALT activities compared with the control and other groups. All physical characteristics in fresh and thawed semen were higher $(\mathrm{P}<0.05)$ in all treated groups than in the control group, being the best in G4. Plasma testosterone and total antioxidant capacity concentrations were increased $(\mathrm{P}<0.05)$ in $\mathrm{G} 4, \mathrm{G} 3$ and $\mathrm{G} 2$ compare with the control $(\mathrm{G} 1)$, being the best for G4 bulls. In conclusion, an oral dose of $1.5 \mathrm{~g}$ NAC plus $1.5 \mathrm{~g} \mathrm{L-C} \mathrm{bull/day,} \mathrm{as} \mathrm{a} \mathrm{combination,}$ for 2 months pre-semen collection improves health status, immunity response and antioxidant capacity of buffalo bulls to produce semen with high quality require for spreading the tool of artificial insemination in buffaloes.

Keywords: Buffaloes, $N$-acetylcysteine, L-carnitine, semen quality, blood and testosterone.

\section{INTRODUCTION}

All over the world, buffaloes are economic farm animals for the production of milk and meat. There is a need for researches to improve several considerations for the importance of buffalo (Michelizzi et al., 2010). Male is a factor remaining a common reason of infertility; thus, it important to accurate assessment of semen quality with improving buffalo bull semen cryopreservation for animal breeding. Buffalo semen with good quality is require for natural breeding and artificial insemination (AI) to increase the reproductive efficiency of buffalo females (Wafa et al., 2017).

Oxidative stress (OS) has been identified as a major mediator in various etiologies of male infertility, the release of harmful decay products such as reactive oxygen species (ROS) can increases defective spermatozoa that led to decreasing the total number of fertilization-competent spermatozoa in AI semen doses (Thundathil et al., 2001; Aitken et al., 2006).Therefore, gains in sperm viability and a reduction of the minimum necessary sperm number per AI dose could be achieved by the supplementation antioxidants and by the development of simple, rapid, and inexpensive techniques for the removal of defective spermatozoa (Petruska et al., 2014). The treatments of oxidative stress, including oral antioxidants, have been widely studied in patients with infertility caused by reactive oxygen species (ROS) directly or indirectly (Agarwal et al., 2014). 


\section{El-Nagar et al.}

Low molecular weight compounds such as N-acetylcysteine (NAC) and carnitine are protective antioxidant system comprehends, enzymatic, non-enzymatic factors which interact each other to ensure an optimal protection against the oxidative stress. A deficiency in one of these antioxidants may result in a decrease of total plasma antioxidant capacity (Walczak-Jedrzejowska et al., 2013). NAC is a nucleophilic amino acid that is converted in the body to cysteine, a precursor to glutathione which is the main endogenous antioxidant against lipid peroxidation in the epididymis and testes (Mora-Esteves and Shin, 2013). NAC exerts its antioxidant actions essentially by two mechanisms. It is capable of easily penetrating cellular membranes and, once inside the cells. Although extensive research has been made in the antioxidant protective effects of NAC on ROS-induced side effects (Lanzafame et al., 2009; De la Cruz Rodriguez et al., 2010; Wang et al., 2014), the amount of studies focused on male fertility is scarce. NAC has free radical scavenging activity both in vivo (Ciftci et al., 2009) and in vitro (Hussein, 2018). Carnitine is a high-polarity natural compound, similar to vitamins-like amino acids. Within the body of most animals, it is synthesized from lysine and methionine. It is a water soluble antioxidant, especially in its forms L-carnitine (Vaz and Wanders, 2002). High concentrations of carnitine are present in the male reproductive tract and particularly in the epididymis, suggesting its crucial role in energy metabolism and sperm maturation ( $\mathrm{Ng}$ et al., 2004). L-carnitine (L-C) involves in sperm motility as it is considered a source of energy, and it is acts as an essential co-factor for the transport of long chain fatty acids within the mitochondrial matrix in order to facilitate the oxidative processes and to enhance cellular energy production(Agarwal and Said, 2004).

Daily treatment with NAC results in a significant improvement in sperm function by reducing ROS and oxidation of sperm DNA (Safarinejad and Safarinejad, 2009; Jannatifar et al., 2019). Also, oral treatment with NAC (600 mg daily) was associated with significant improvement in sperm motility with idiopathic infertility in human (Ciftci et al., 2009). Friesian bulls, high-quality semen was produce by oral dose of $2 \mathrm{~g} / \mathrm{h} / \mathrm{L}-\mathrm{C}$ for 2 months (Abdel-Khalek et al., 2015), and increased sperm motility and pregnancy rate in human (Lenzi et al., 2004; Balercia et al., 2005). Also, addition of L-C on semen extender of cryopreserved semen improves sperm activity (Banihani et al., 2014; Hussein, 2018).

Therefore, this study aimed to the impact of NAC, L-C or their combination as oral dose for 2 months pre-semen collection on sexual desire, semen production, blood biochemicals and hematological parameters, antioxidant and health statues of Egyptian buffaloe.

\section{MATERIALS AND METHODS}

The experimental work of this study was done at Animal Production Research Institute (APRI), Egypt, in cooperation with Department of Animal Production, Faculty of Agriculture, Tanta University.

\section{Animals and experimental design:}

A total of twenty healthy Egyptian buffalo bulls weighing $400 \pm 37.5 \mathrm{~kg}$ and $24-25$ months old were divided to four experimental groups according to age and body weight ( 5 bulls in each). The control bulls received a basal diet without treatments (G1). Each bull in G2, G3, and G4 receive the control diet with daily oral-dose of $3 \mathrm{~g} \mathrm{~L}-\mathrm{C}, 3 \mathrm{~g}$ NAC and $1.5 \mathrm{~g} \mathrm{NAC}+1.5 \mathrm{~g} \mathrm{~L}-\mathrm{C}$ for 2 months a treatment period, respectively. The experimental bulls were kept under the same conations of housing (individually in semi-open sheds), environment and management.

\section{Feeding system:}

The experimental bulls in all groups receive individual feeding on a diet containing concentrate feed mixture (CFM), berseem hay (BH) and rice straw (RS) according to APRI buffalo bull requirements. Feeds were offered at 7 a.m. and 4 p.m., while drinking water was offered all day time. Ingredients and chemical analysis of different feedstuffs are presented in Table (1). 
Table (1): Chemical analysis of CFM, BH an RS in the basal ration of the experimental bulls.

\begin{tabular}{lccccccc}
\hline \multirow{2}{*}{ Item } & \multirow{2}{*}{$\mathrm{DM}$} & \multicolumn{5}{c}{ Chemical analysis (\%, on DM basis) } \\
\cline { 3 - 7 } & & $\mathrm{OM}$ & $\mathrm{CP}$ & $\mathrm{EE}$ & $\mathrm{CF}$ & $\mathrm{NFE}$ & $\mathrm{ASH}$ \\
\hline Concentrate feed mixture & 91.50 & 88.74 & 15.85 & 4.70 & 13.66 & 54.53 & 11.26 \\
Rice straw & 92.30 & 79.63 & 3.47 & 1.41 & 35.10 & 39.65 & 20.37 \\
Berseem hay & 89.00 & 85.96 & 15.96 & 2.92 & 28.2 & 38.88 & 14.04 \\
\hline DM= Dry matter, OM= Organic matter, $C P=$ Crude protein, CF $=$ Crude fiber, EE $=$ Ether extract &
\end{tabular}

\section{Semen collection:}

After a treatment period of two months with different types of antioxidants, semen was collected twice a week using an artificial vagina (IMV, France) for 2 months (collection semen period). The collected semen of each group was individually placed in a water bath $\left(37^{\circ} \mathrm{C}\right)$, and then taken immediately to the laboratory for evaluation of fresh semen. During the collection period, the reaction time (RT) was recorded in term of time elapsed from exposing each bull to a suitable stimulus and the first copulation.

At the last week of the collection period, one half of each ejaculate after evaluation was centrifuged at $3000 \mathrm{rpm}$ for 15 minutes at room temperature to obtain the individual samples of the seminal plasma (Khan et al., 2015), which stored at $-20^{\circ} \mathrm{C}$ until analyses. The second half of the ejaculates was prepared for freezing process.

\section{Semen cryopreservation:}

The collected ejaculates of all bulls in each group were pooled per collection day, then semen was diluted by Tris-base extender (TEY) with $\mathrm{pH}$ value of 6.8 and osmolarity level of 280-300 mOsm/l at a rate of 1:10 (semen: extender). The TEY contained $3.63 \mathrm{~g}$ tris, $0.5 \mathrm{~g}$ fructose, $1.99 \mathrm{~g}$ citric acid, $100 \mathrm{mg}$ streptomycin, and $100.000 \mathrm{IU}$ penicillin dissolved in $100 \mathrm{ml}$ distilled water. In $83 \mathrm{ml}$ of TEY extender, egg yolk $(10 \mathrm{ml})$ and glycerol $(7 \mathrm{ml})$ were added. After cooling the diluted semen at $5^{\circ} \mathrm{C}$ for $4 \mathrm{~h}$ as an equilibration period, semen was aspired into $0.25 \mathrm{ml}$ French straws, then straws were sealed using polyvinyl alcohol powder and expose for $10 \mathrm{~min}$ at $5 \mathrm{~cm}$ above liquid nitrogen (LN) vapor, then plunged into $\mathrm{LN}\left(-196^{\circ} \mathrm{C}\right)$, stored one month. During evaluation of semen, the straws were warmed at $37^{\circ} \mathrm{C}$ for 30 second in a water bath.

\section{Evaluation of semen:}

Percentages of progressive motility, livability, abnormality, and acrosomal status of sperm cell were performed according to Amman and Hammerstedt (1980), Hackett and Macpherson (1965), Blom (1983), and Yanagimachi (1982), respectively, in fresh and thawed semen. Also, sperm cell concentration per $\mathrm{ml}$ was determined to calculate total sperm output/ejaculate. Sperm cell concentration/ml (SCC), was estimsted by Haemocytometer (Khan, 1994). Total sperm output/ejaculate (TSO) was compute using the following formula: TSO = Ejaculate volume $(\mathrm{ml}) \times \mathrm{SCC} / \mathrm{ml}$. Total antioxidant concentration was also determined in post-thawed semen according to Koracevic et al. (2001).

\section{Blood samples:}

At the end of experiment, blood samples were taken before morning feeding from animals in each group via the jugular vein into test tubes containing heparin (anticoagulant). Each blood samples were divided to 2 portions; the first was centrifuged at $3000 \mathrm{rpm}$ for 15 minutes to separate blood plasma, while the second were prepared for hematological parameters.

Blood plasma samples were kept at $-20^{\circ} \mathrm{C}$ till determination of total proteins (Tietz, 1990) and albumin (Tietz, 1994) concentrations. Globulin concentration was obtained by subtracting the concentration of albumin form the total proteins. Concentrations of triglycerides, total cholesterol, 


\section{El-Nagar et al.}

creatinine, and glucose in blood plasma were also determined according to Mc Gowan et al. (1983), Richmond (1973), Bartles et al. (1972), Trinder (1969) according to Reitman and Frankal (1957), activity of asprtate (AST) and alanine (ALT) aminotransferases in blood plasma was determined.

Concentrations of testosterone (Ekins, 1984) and total antioxidants (Koracevic et al., 2001) in blood plasma were determined. Plasma biochemicals in plasma were calorimetrically determined using spectrophotometer and by commercial kits (diagnostic system laboratories, INC, USA).

Blood hematology involved counts of erythrocyte (RBCs) and luekocytes (WBCs) were counted using Haemocytometer, while haemoglobin $(\mathrm{Hb})$ concentration and hematocrit (PCV \%) were directly measured according to Henry (2001) by commercial kits (Mission® Plus, REF C132-3031, USA).

\section{Statistical analysis:}

The obtained results were statistically analyzed by SPSS (2013) to study the effect of treatment on different variables using one way-ANOVA. The significant mean differences were set by Duncan Multiple Range Test (Duncan, 1955) at $\mathrm{P}<0.05$.

\section{RESULTS AND DISCUSSION}

\section{Semen production and sperm output:}

Results presented in Table (2) showed that the sexual desire in term of reaction time and all semenquality parameters of buffalo bulls were improved significantly $(\mathrm{P}<0.05)$ in treatment groups $\mathrm{G} 2, \mathrm{G} 3$, and $\mathrm{G} 2$ in comparing with untreated-control group (G1). The maximal beneficial effects were recorded in G4 for buffalo bulls treated with L-C and NAC combination.

Table (2): Effect of L-carnitine (L-C), N-acetylcysteine (NAC), or their combination on sexual desire and semen parameters in buffalo bulls.

\begin{tabular}{lcccc}
\hline \multirow{2}{*}{ Semen trait } & \multicolumn{4}{c}{ Experimental group } \\
\cline { 2 - 5 } & G1 & G2 & G3 & G4 \\
& (Control) & $(\mathrm{LC})$ & $(\mathrm{NAC})$ & $(\mathrm{LC}+\mathrm{NAC})$ \\
\hline Reaction time (second) & $95.83 \pm 1.08^{\mathrm{a}}$ & $67.78 \pm 0.89^{\mathrm{b}}$ & $66.63 \pm 0.90^{\mathrm{b}}$ & $59.03 \pm 0.65^{\mathrm{c}}$ \\
Ejaculate volume, ml & $2.12 \pm 0.09^{\mathrm{c}}$ & $2.59 \pm 0.09^{\mathrm{b}}$ & $2.63 \pm 1.00^{\mathrm{b}}$ & $3.21 \pm 0.08^{\mathrm{a}}$ \\
Progressive sperm motility, \% & $66.67 \pm 0.50^{\mathrm{c}}$ & $72.53 \pm 0.89^{\mathrm{b}}$ & $72.78 \pm 0.88^{\mathrm{b}}$ & $77.72 \pm 1.11^{\mathrm{a}}$ \\
Live sperm, \% & $68.58 \pm 0.67^{\mathrm{c}}$ & $74.08 \pm 0.88^{\mathrm{b}}$ & $75.00 \pm 0.85^{\mathrm{b}}$ & $78.83 \pm 1.08^{\mathrm{a}}$ \\
Abnormal sperm, \% & $26.05 \pm 0.39^{\mathrm{a}}$ & $17.70 \pm 0.72^{\mathrm{b}}$ & $17.42 \pm 0.74^{\mathrm{b}}$ & $13.67 \pm 0.98^{\mathrm{c}}$ \\
Acrosomal damage, \% & $25.28 \pm 0.41^{\mathrm{a}}$ & $19.60 \pm 0.40^{\mathrm{b}}$ & $19.43 \pm 0.39^{\mathrm{b}}$ & $14.58 \pm 0.66^{\mathrm{c}}$ \\
Sperm concentration, x10 $/ \mathrm{ml}$ & $0.848 \pm 0.04^{\mathrm{c}}$ & $1.098 \pm 0.03^{\mathrm{b}}$ & $1.251 \pm 0.07^{\mathrm{a}}$ & $1.350 \pm 0.05^{\mathrm{a}}$ \\
Total sperm output, x10 $/$ ejac. & $1.809 \pm 0.13^{\mathrm{c}}$ & $2.913 \pm 0.18^{\mathrm{b}}$ & $3.371 \pm 0.29^{\mathrm{b}}$ & $4.381 \pm 0.26^{\mathrm{a}}$ \\
\hline
\end{tabular}

$a, b$, and $c$ : Group differences within each row at $P<0.05$.

In comparing our result with other authors, the dietary addition of L-C improved semen quality (Jacyno et al., 2007), and increased the ejaculate volume and concentration of spermatozoa in boar (Wahrner et al., 2004). Dietary L-C supplementation increased ejaculate volume and sperm viability of boar (Akey, 2000). Generally, previous studies suggested that male infertility may be treated by carnitine (Matalliotakis et al., 2000; Lenzi et al., 2003). The L-C plays an important role as an antioxidant. It increased number of sperm cells (Zhai et al., 2007) as well as progressive sperm motility and vitality in infertile males (Vicari and Calogero, 2001) via preventing the lipid peroxidation by decreasing ROS production patients.

On the other hand, NAC is protective antioxidant system comprehend acts as protectors of oxidative stress. It improves the total plasma antioxidant capacity (Walczak-Jedrzejowska et al., 2013) against lipid peroxidation in the epididymal and testicular tissues (Mora-Esteves and Shin, 2013) and protecting from ROS-induced side effects (Wang et al., 2014). It was reported that NAC has in vivo (Ciftci et al., 2009) and in vitro (Hussein, 2018) free radical scavenging activity. In similar pattern, NAC and L-C act as key role in sperm metabolism. They proved readily available energy for sperm cell activity that has a positive 
effect on sperm mobility (Matalliotakis et al., 2000). A secondary role of NAC and L-C as antioxidants is counteracting and eliminating several body oxidation factors and protecting the normality and physiological function of body cells (Dokmeci, 2005).

\section{Characteristics of the seminal plasma:}

It was observed that total cholesterol (TC), triglycerides (TG) concentrations, and AST and ALT activity significantly $(\mathrm{P}<0.05)$ decreased, while level of total antioxidant capacity significantly $(\mathrm{P}<0.05)$ increased in seminal plasma of bulls by all treatments. Treatment of bulls with L-C and NAC combination showed significantly $(\mathrm{P}<0.05)$ the highest positive impact on lipid profile, membrane integrity and antioxidant status of the seminal plasma of buffalo bulls (Table 3).

Table (3): Effect of L-carnitine (L-C), N-acetylcysteine (NAC), or their combination on chemical composition, enzyme activity, and total antioxidant capacity of the seminal plasma of fresh buffalo semen.

\begin{tabular}{|c|c|c|c|c|}
\hline \multirow{2}{*}{ Item } & \multicolumn{4}{|c|}{ Experimental group } \\
\hline & G1 (Control) & G2 (LC) & G3 (NAC) & G4 (LC+NAC) \\
\hline \multicolumn{5}{|c|}{ Seminal plasma biochemical } \\
\hline Total cholesterol, g/dl & $96.89 \pm 2.35^{\mathrm{a}}$ & $88.97 \pm 2.26^{\mathrm{b}}$ & $84.31 \pm 1.99^{\mathrm{bc}}$ & $80.34 \pm 1.71^{\mathrm{c}}$ \\
\hline Triglyceride, $\mathrm{g} / \mathrm{dl}$ & $46.32 \pm 1.02^{\mathrm{a}}$ & $39.21 \pm 1.13^{\mathrm{b}}$ & $37.65 \pm 0.97^{\mathrm{b}}$ & $33.86 \pm 0.76^{\mathrm{c}}$ \\
\hline \multicolumn{5}{|c|}{ Enzyme activity in seminal plasma: } \\
\hline AST, IU/1 & $57.78 \pm 1.35^{\mathrm{a}}$ & $46.71 \pm 1.13^{\mathrm{b}}$ & $45.32 \pm 1.12^{\mathrm{b}}$ & $40.29 \pm 1.94^{\mathrm{c}}$ \\
\hline $\mathrm{ALT}, \mathrm{IU} / \mathrm{l}$ & $26.34 \pm 0.81^{\mathrm{a}}$ & $22.41 \pm 0.47^{\mathrm{b}}$ & $21.05 \pm 0.51^{\mathrm{b}}$ & $18.84 \pm 0.31^{\mathrm{c}}$ \\
\hline \multicolumn{5}{|c|}{ Total Antioxidant in seminal plasma: } \\
\hline $\mathrm{TAC}(\mathrm{mM} / \mathrm{l})$ & $1.75 \pm 0.18^{\mathrm{c}}$ & $2.63 \pm 0.19^{\mathrm{b}}$ & $2.88 \pm 0.18^{\mathrm{b}}$ & $3.63 \pm 0.18^{\mathrm{a}}$ \\
\hline
\end{tabular}

$a, b$, and $c$ : Group differences within each row at $P<0.05$.

Activity of transaminases AST and ALT in the seminal plasma is used as an indicator of sperm membrane integrity because releasing sperm enzymes into the seminal plasma was found to be in association with injury in spermatozoa (Rasul et al., 1999). Therefore, decreasing the activity of AST and ALT in the seminal plasma of all treatment groups, especially those treated with L-C and NAC combination may indicate intact plasma membrane, normality and viable sperm cells (Daader et al., 1993; Abdel-Gawad et al., 2000). Similar results were reported regarding the effect of treatment on antioxidant status of the seminal plasma, In this context, using Moringa oleifera leaves (MOL), as a natural antioxidant, significantly decreased serum TC and TG concentrations in buffalo bulls, and increased activity of catalase, glutathione (GSH) and SOD as antioxidant enzymes (Wafa et al., 2017). In rabbits, the MOL extract could decrease concentrations of TC and TG (Chumark et al., 2008). Lipid peroxidation in blood was decreased in rabbit bucks by MOL extract (El-Harairy et al., 2016). This may be due to the high content of flavonoids in MOL (Asma et al., 2005).

\section{Sperm freezing ability:}

Data presented in Table (4) clear that all sperm characteristics in thawed semen of buffalo bulls including percentages of progressive motility, livability, abnormality, acrosomal damage of sperm cells as well as TAC level showed significant $(\mathrm{P}<0.05)$ improvement with $\mathrm{G} 2$ an $\mathrm{G} 3$ in comparing with $\mathrm{G} 1$.

Table (4): Effect of L-carnitine (L-C), N-acetylcysteine (NAC), or their combination on freezing ability and total antioxidant capacity of buffalo semen.

\begin{tabular}{lcccc}
\hline \multirow{2}{*}{ Item } & \multicolumn{3}{c}{ Experimental group } \\
\cline { 2 - 5 } & G1 (Control) & G2 (LC) & G3 (NAC) & G4 (LC+NAC) \\
\hline \multicolumn{2}{l}{ Sperm characteristics in thawed semen: } & & & \\
Progressive sperm motility, $\%$ & $45.15 \pm 0.66^{\mathrm{d}}$ & $57.95 \pm 0.50^{\mathrm{c}}$ & $59.85 \pm 0.64^{\mathrm{b}}$ & $63.10 \pm 0.57^{\mathrm{a}}$ \\
Live sperm, \% & $47.00 \pm 0.70^{\mathrm{c}}$ & $58.95 \pm 0.80^{\mathrm{b}}$ & $60.35 \pm 0.68^{\mathrm{b}}$ & $63.90 \pm 0.84^{\mathrm{a}}$ \\
Abnormal sperm, \% & $48.90 \pm 0.67^{\mathrm{a}}$ & $27.30 \pm 0.56^{\mathrm{b}}$ & $26.60 \pm 0.37^{\mathrm{b}}$ & $19.70 \pm 0.47^{\mathrm{c}}$ \\
Acrosomal damage, \% & $49.00 \pm 0.79^{\mathrm{a}}$ & $31.70 \pm 0.87^{\mathrm{b}}$ & $30.50 \pm 0.62^{\mathrm{b}}$ & $22.70 \pm 0.50^{\mathrm{c}}$ \\
Total antioxidant capacity (TAC) of the thawed seminal plasma: & & \\
TAC (mM/l) & $2.87 \pm 0.24^{\mathrm{b}}$ & $3.10 \pm 0.23^{\mathrm{ab}}$ & $3.22 \pm 0.23^{\mathrm{ab}}$ & $3.75 \pm 0.29^{\mathrm{a}}$ \\
\hline
\end{tabular}

$a, b$, and $c$ : Group differences within each row at $P<0.05$. 


\section{El-Nagar et al.}

Buffalo bulls treated with L-C and NAC combination showed the highest benefits on freezing ability of cryopreserved semen, which was in harmony with semen physical characteristics of the same bulls in fresh semen.

The obtained results are in accordance with those reported on the impact of antioxidant supplementation in semen extender during cryopreservation by different species. In buffalo bulls, ElSheltawi et al. (1999) showed that post-thawing motility was proved to be higher than control after in vivo and/or in vitro supplementation of vitamin E. El-Siefy (2004) demonstrated that post-thaw progressive motility after 30 days of deep freezing was improved in bulls treated with selenium plus vitamin E. El-Hawary (2010) showed that sperm characteristics were proved to be higher $(\mathrm{P}<.0 .0)$ in post-thawed semen of buffalo bulls treated with vitamin E + Zinc than control. In rams, Gokcen et al. (1990) indicated that rams supplemented with different antioxidant were significantly better in the frozen semen characteristics and acrosomal morphology of spermatozoa than that of non- supplemented rams.

Biochemicals, enzyme activity, testosterone profile and total antioxidant capacity in blood plasma:

The concentrations of biochemicals including total proteins (TP), albumin (AL), globulin (GL), and glucose increased $(\mathrm{P}<0.05)$, while total cholesterol, triglycerides and creatinine decreased $(\mathrm{P}<0.05)$ in blood plasma of bulls with groups G2, G3 and G4 than control group. In addition, AST and ALT activities reduced $(\mathrm{P}<0.05)$, however, testosterone and TAC levels were improved $(\mathrm{P}<0.05)$ in blood plasma in all treatment groups. Generally, among all treatments L-C and NAC combination reflected the highest improvement on protein and carbohydrate metabolism, lipid profile, kidney and liver function, antioxidant defense system, and sexual desire of buffalo bulls (Table 5).

Table (5): Effect of L-carnitine (L-C), N-acetylcysteine (NAC), or their combination some biochemicals, enzyme activity, testosterone profile and total antioxidant capacity in blood plasma of buffalo bulls.

\begin{tabular}{lcccc}
\hline \multirow{2}{*}{ Item } & \multicolumn{4}{c}{ Experimental group } \\
\cline { 2 - 5 } & G1 (Control) & G2 (LC) & G3 (NAC) & G4 (LC+NAC) \\
\hline Blood biochemicals: & & & & \\
Total proteins, g/dl & $7.24 \pm 0.24^{\mathrm{c}}$ & $8.14 \pm 0.25^{\mathrm{b}}$ & $8.48 \pm 0.25^{\mathrm{b}}$ & $9.46 \pm 0.37^{\mathrm{a}}$ \\
Albumin, g/dl & $3.01 \pm 0.18^{\mathrm{b}}$ & $3.42 \pm 0.17^{\mathrm{b}}$ & $3.50 \pm 0.15^{\mathrm{b}}$ & $4.62 \pm 0.37^{\mathrm{a}}$ \\
Globulin, g/dl & $4.23 \pm 0.16^{\mathrm{b}}$ & $4.73 \pm 0.18^{\mathrm{ab}}$ & $4.97 \pm 0.17^{\mathrm{a}}$ & $4.83 \pm 0.22^{\mathrm{a}}$ \\
Total cholesterol, g/dl & $172.04 \pm 5.26^{\mathrm{a}}$ & $149.42 \pm 4.13^{\mathrm{b}}$ & $149.59 \pm 2.57^{\mathrm{b}}$ & $134.84 \pm 2.14^{\mathrm{c}}$ \\
Triglycerides, g/dl & $60.44 \pm 1.55^{\mathrm{a}}$ & $53.04 \pm 1.50^{\mathrm{b}}$ & $53.62 \pm 1.82^{\mathrm{b}}$ & $49.48 \pm 1.39^{\mathrm{b}}$ \\
Creatinine, mg/dl & $0.88 \pm 0.02^{\mathrm{a}}$ & $0.71 \pm 0.04^{\mathrm{b}}$ & $0.68 \pm 0.03^{\mathrm{b}}$ & $0.62 \pm 0.04^{\mathrm{b}}$ \\
Glucose, mg/dl & $57.82 \pm 1.54^{\mathrm{c}}$ & $61.55 \pm 0.46^{\mathrm{b}}$ & $63.57 \pm 0.85^{\mathrm{ab}}$ & $66.19 \pm 0.80^{\mathrm{a}}$ \\
Enzyme activity: & & & \\
AST, IU/l & $59.03 \pm 1.25^{\mathrm{a}}$ & $51.45 \pm 1.53^{\mathrm{b}}$ & $50.54 \pm 1.18^{\mathrm{b}}$ & $46.79 \pm 0.85^{\mathrm{c}}$ \\
ALT, IU/l & $23.74 \pm 0.49^{\mathrm{a}}$ & $18.51 \pm 0.37^{\mathrm{b}}$ & $17.15 \pm 0.36^{\mathrm{c}}$ & $15.68 \pm 0.32^{\mathrm{d}}$ \\
Testosterone and total antioxidant capacity (TAC) & & & \\
Testosterone (ng/ml) & $5.12 \pm 0.07^{\mathrm{d}}$ & $6.65 \pm 0.06^{\mathrm{c}}$ & $6.97 \pm 0.07^{\mathrm{b}}$ & $7.59 \pm 0.09^{\mathrm{a}}$ \\
TAC (mM/l) & $2.33 \pm 0.13^{\mathrm{c}}$ & $3.48 \pm 0.18^{\mathrm{b}}$ & $3.92 \pm 0.17^{\mathrm{b}}$ & $4.59 \pm 0.23^{\mathrm{a}}$ \\
\hline
\end{tabular}

$a, b$, and $c$ : Group differences within each row at $P<0.05$

These results may be in association with the antioxidant properties of L-C, NAC or the synergic effects of their combination on antioxidant defense system by protecting body cells from the harmful effects of ROS due to lipid peroxidation. In this respect, many authors found a significant positive effect of antioxidants (MOL), as a dietary supplement, on increasing the concentration of TP, AL, GL, glucose, testosterone and TAC, and reducing total cholesterol, triglycerides, and creatinine concentrations as well as AST and ALT activities in blood of buffalo bulls (Wafa et al., 2017) and rabbit bucks (El-Ratel, 2017). Supplementation of L-C significantly increased glucose concentration in blood of rabbits (Chapa et al., 2001). However, NAC treatment was found to improve biochemical parameters in serum, decrease the hepatoxicity, in term of reducing activity of AST and ALT of Wistar male rats severed from toxicity (Turkmen et al., 2019). The hepatoprotective effects of NAC may be attributed to that NAC supplementation resulting attenuation of liver damage (Lasram et al., 2014). The indicated hepatoprotective effect of NAC might be attributed to the homeostasis in the oxidant/antioxidant status supplied by NAC (Turkmen et al., 2019). In our study, the NAC alone or in combination with L-carnitine 
showed protection against oxidative stress injury to keep the structural integrity of hepatic cells preventing release of intracellular enzymes into the blood (Izadia et al. 2011).

The noted association between testosterone concentration and TAC was reported by Jannatifar et al. (2019). This may reflect that all treatments, in particular their combination, had beneficial effect lipid peroxidation and oxidative stress index (Agarwal and Majzoub, 2017). Therefore, the improvement observed in fresh semen of all treatment groups was mainly due to improving the concentration of testosterone and TAC levels.

Based on the present results, treatment with L-C, NAC, or their combination had no effect on liver and kidney function, but positively affected antioxidant defense mechanism (Asal Lamiaa, 2013).

\section{Hematological parameters:}

Results concerning hematological parameters of buffalo bulls as shown in Table (6) revealed that count of red blood cells (RBCs), hemoglobin concentration ( $\mathrm{Hb}$ ) and packed cell volume (PCV) showed significant $(\mathrm{P}<0.05)$ improvement in treatment groups $\mathrm{G} 4, \mathrm{G} 3$ and G2 compared with G1. Count of WBCs decreased significantly $(\mathrm{P}<0.05)$ in $\mathrm{G} 2$ and G4 compared with G1. Treatment with L-C and NAC combination showed the best impact on all hematological parameters of buffalo bulls, exhibiting synergetic effect of L-C and NAC on blood hematology of buffalo bulls. Similar results indicated improvement of hematological parameters of buffalo bulls treated with MOL (Wafa et al., 2017), and the Nubian Sudanese goats fed on MOL (Babeker and Abdalbagi, 2015) as antioxidants. In general agreement with the present results, natural antioxidant administrations have beneficial effects on hematological parameters of different species, including the impact of green tea extract on rabbit does (El-Ratel et al., 2017), rabbit bucks treated with lycopene (El-Ratel, 2017), rabbit bucks treated with propolis (Hashem et al., 2013), impact of MOL extract on rabbit bucks (Chumark et al., 2008; Chinwe and Isitua, 2010; Ahemen et al., 2013).

Table (6): Effect of L-carnitine (L-C), N-acetylcysteine (NAC), or their combination on some hematological parameters in buffalo bulls.

\begin{tabular}{lcccc}
\hline \multirow{2}{*}{ Item } & \multicolumn{4}{c}{ Experimental group } \\
\cline { 2 - 5 } & G1 (Control) & G2 (LC) & G3 (NAC) & G4 (LC+NAC) \\
\hline RBC $\left(\times 10^{6} / \mathrm{mm}^{3}\right)$ & $6.43 \pm 0.19^{\mathrm{c}}$ & $7.44 \pm 0.17^{\mathrm{b}}$ & $7.53 \pm 0.13^{\mathrm{b}}$ & $8.27 \pm 0.15^{\mathrm{a}}$ \\
$\mathrm{WBC}\left(\times 10^{3} / \mathrm{mm}^{3}\right)$ & $7.73 \pm 0.18^{\mathrm{a}}$ & $7.10 \pm 0.14^{\mathrm{bc}}$ & $7.46 \pm 0.15^{\mathrm{ab}}$ & $6.97 \pm 0.15^{\mathrm{c}}$ \\
$\mathrm{Hb}(\mathrm{mg} / \mathrm{dl})$ & $7.92 \pm 0.25^{\mathrm{c}}$ & $9.19 \pm 0.27^{\mathrm{b}}$ & $9.12 \pm 0.23^{\mathrm{b}}$ & $10.36 \pm 0.28^{\mathrm{a}}$ \\
$\mathrm{PCV}(\%)$ & $31.44 \pm 0.51^{\mathrm{c}}$ & $33.59 \pm 0.26^{\mathrm{b}}$ & $33.83 \pm 0.25^{\mathrm{ab}}$ & $34.71 \pm 0.17^{\mathrm{a}}$ \\
\hline
\end{tabular}

$a, b$, and $c$ : Group differences within each row at $P<0.05$. RBC $=$ Red blood cells, WBC=White blood cells, $H b=$ Hemoglobin, PCV=Packed cell volume.

In the presence of unchecked ROS accumulation, hematopoietic cells appear to be particularly vulnerable, because the deficiency in antioxidant defense system leads to either anemia and/or hematopoietic tissues malignancies (Kong et al., 2004). Therefore, the improvement observed in hematological parameters of buffalo bulls by treatment of L-C, NAC or their combination in our study may be related to the impact of these treatments as antioxidants by protecting against ROS generation in haematopoietic cells.

\section{CONCLUSION}

In conclusion, oral dose of $1.5 \mathrm{~g}$ NAC plus $1.5 \mathrm{~g} \mathrm{L-C}$ bull/day, as a combination, for 2 months presemen collection improves health status, immunity response and antioxidant capacity of buffalo bulls to achieve high quality semen for spreading the artificial insemination with buffalo semen with high fertility. 


\section{El-Nagar et al.}

\section{REFERENCES}

Abdel-Gowad, E. I.; T. A. Taha and M. Ayoub (2000). Monthly and season variations in seminal plasma constituents of Barki, Damascus and their cross under subtropical conditions. Proc., 3rd All African Conf. Animal. Agri. \& 11th Conf. Egyptian Soc. Animal Prod. 491.

Abdel-Khalek, A.E.; H. K. Zaghlool and Sh. A. Gabr (2015). Performance and Semen Traits of Friesian Bulls Administrated with Free L-Carnitine as Metabolic Regulator. Asian Journal of An. Sc. V. 9 (1): 13-24.

Agarwal, A. and T. M. Said (2004) Carnitines and male infertility. Reprod BioMed Online, 8(4): 376384.

Agarwal, A.; E. Tvrda and R. Sharma (2014). Relationship amongst teratozoospermia, seminal oxidative stress and male infertility. Reprod BiolEndocrinol, 12: 45.

Agarwal, A. and A. Majzoub (2017). Role of Antioxidants in Assisted Reproductive Techniques. World J Mens Health Published online April 30, 1-17.

Ahemen, T.; H. Abu. Adakole and K. Lois (2013). Iorgilim Physiological responses of rabbits fed graded levels of Moringa oleifera leaf meal (MOLM): Some aspects of haematology and serum biochemistry. Archives of Applied Science Research, 5 (2):172-176.

Aitken, R. J.; J. K. Wingate; G. N. De Iuliis; A. J. Koppers and E. A. McLaughlin (2006). Cisunsaturated fatty acids stimulate reactive oxygen species generation and lipid peroxidation in human spermatozoa. J Clin Endocrinol Metab.; 91: 4154-4163.

Akey, S. N.( 2000). Akey's field trial experience with L-carnitine supplementation of sow diets. Swine Newsletter April 2000, Akey Inc., Lewisburg, OH., USA., pp: 1-2.

Amman, R. P. and R. H. Hammerstedt (1980). Validation of a system for computerized measurements of spermatozoa velocity and percentage of motile soerm. Biol. Repro. 23: 647 - 656 (A. B. A. 1981) Vol. 99 (8): 4508.

Asal Lamiaa, F.A. (2013). Biological role of natural antioxidant for decreasing the damage impact of free radicals under aging and heat stress condition in rabbits. Ph. D degree. Animal and Fish Production Dept. Faculty of Agriculture Alexandria University.

Asma, S.; A. Farooq; M. Maleeha and F. Ammara (2005). Antioxidant activity of different solvent extracts of Moringa oleifera leaves under accelerated storage of sunflower oil. Asian Jour. of Plant Sci., 4(6): 630-635.

Babeker, E. A. and Y. M. Abdalbagi (2015). Effect of feeding different levels of moringa oleifera leaves on performance, haematological, biochemical and some physiological parameters of Sudan Nubian goats. Online Journal of Animal and Feed Research. Vol. 5, Issue 2: 50-61.

Balercia. G.; F. Regoli; T. Armeni; A. Koverech; F. Mantero and M. Boscaro (2005). Placebo controlled double-blind randomized trial on the use of L-carnitine, L-acetylcarnitine, or combined L-carnitine and L-acetylcarnitine in men with idiopathic asthenozoospermia. Fertil Steril, 84:662-71.

Banihani, S.; A. Agarwal; R. Sharma and M. Bayachou (2014). Cryoprotective effect of 1-carnitine on motility, vitality and DNA oxidation of human spermatozoa. Andrologia, 46(6): 637-641.

Bartles, H.; Bohmer, M.; Heirli, C. (1972): Clin. Chem. Acta, 37:193.

Blom, E. (1983). The spermiogram of the bull. Nordisk Veterinear Medicin., 35:105.

Chapa, A .M.; J. M. Fernandez; T.W. White; L. D. Bunting; L. R. Gentry: J. C. Lovejoy and K. Q. Owen (2001). Influence of dietary carnitine in growing sheep fed diets containing non-protein nitrogen. Small Rumin. Res., 40: 13-28.

Chinwe, C. and N. Isitua (2010). Studies on the haematological impact of Moringa oleifera in rabbits. A poster presented at 2nd Internationals Conference on Applied Biotechnology, October 25-27, Khartoum, Sudan.

Chumark, P.; P. Khunawat; Y. Sanvarinda; S. Phornchirasilp; N. P Morales; L. Phivthong-ngam; P. Ratanachamnong; S. Srisawat and Klai-upsorn S. Pongrapeeporn. (2008). The in vitro and ex vivo 
antioxidant properties, hypolipidaemic and antiatherosclerotic activities of water extract of Moringa oleifera Lam. Leaves. Journal of Ethnopharmacology, 1-8.

Ciftci, H.; A. Verit; M. Savas; E. Yeni and O. Erel (2009). Effects of N-acetylcysteine on semen parameters and oxidative/antioxidant status. Urology, 74(1):73-76.

Daader, A. H.; I. F. Merai and A. S. Nasr (1993). Transaminasic and fructolytic activities of buffalo bull sperm semen in relation to some physiological attributes of spermatozoa. In prospects of buffalo production in the Mediterranean and the Middle East. Proceedings of the International Symposium. EAAP. Pub. 62: 198-209.

De la Cruz Rodriguez, L. C.; C. R. Araujo; S. E. Posleman and M. R. Rey (2010). Attenuation of gentamicininduced nephrotoxicity: trimetazidine versus N-acetyl cysteine. J. Appl. Toxicol., 30: 343-353.

Dokmeci, D. (2005). Oxidative stress, male infertility and the role of carnitines. Folia. Med., 47: 26-30.

Duncan, D. B. (1955). Multiple Range and Multiple F. Test Biometrics. 11: 1-42.

Ekins, R. P. (1984). Free hormones in blood: Concept and measurement. J. Clin. Immunoassay, 7: 163180.

El-Harairy, M. A.; A. E. Abdel-Khalek; W. A. Khalil; E. I. Khalifa;A. Y. El-Khateeb and A.M. Abdulrhmn (2016). Effect of Aqueous Extracts of Moringa oleifera leaves or Arctium lappa Roots on Lipid Peroxidation and Membrane Integrity of Ram Sperm Preserved at Cool Temperature.J. Anim. and Poultry Prod., Mansoura Univ., Vol.7 (12 ): 467- 473.

El-Hawary, A. F. E. (2010). Reducing peroxidation process in buffalo semen in response to some antioxidant treatments. Ph. D. Thesis, Fac. of Agric., Mansoura Univ., Egypt.

El-Ratel, I.T. (2017). Impact of lycopene or folic acid treatment on semen quality, blood constituents and fertility of rabbit bucks. Egyptian J. Nutrition and Feeds (2017), 20 (2): 213-223.

El-Ratel, I.T.; A. E. Abdel-Khalek; M. A. El-Harairy; Sara F. Fouda and Lamiaa Y. El-Bnawy (2017). Impact of green tea extract on reproductive performance, hematology, lipid metabolism and histogenesis of liver and kidney of rabbit does. Asian J. Anim. Vet. Adv., 12: 51-60.

El-Sheltawi, M. A.; Mary G. Abdel-Malak; G. Abdel-Malak and T. A. Khalifa (1999). Impact of zinc and tocopherol on functional competence of cryopreserved buffalo spermatozoa. Assuit Vet. Med. J., 42: 291- 309.

El-Siefy, E. M. E. (2004). Reproductive aspects on effect of selenium and vitamin E on semen quality and fertility of Egyptian buffalo bulls./ Ph. D. Thesis, Fac. of Agric., Kafr El-Sheikh, Tanta Univ., Egypt.

Gokcen, H.; H. Camas; H. Erding; R. Asti; E. Cekgul and E. Sener (1990). Studies on the effects of vitamin $\mathrm{E}$ and selenium added to the on acrosome morphology, enzyme activity and fertility of ram spermatozoa. Doga-Turk-Veterinerlik-Ve-Hayvancilik ration frozen Dergisi, 14:2, 207.

Hackett, A. J. and J. W. Macpherson (1965). Some staining procedures for spermatozoa. A review. Can. Vet. J., 5: 55.

Hashem, N. M.; A. N. Abdel-Hady and B.O. Hassan (2013). Effect of vitamin E or propolis supplementation on semen quality, oxidative status and hemato-biochemical changes of rabbit bucks during hot season, Livestock Science, 157:520-526.

Henry, J. B. (2001). Clinical Diagnosis and Management by Laboratory Methods. Twentieth Edition, Page 485.

Hussein, Y. S. (2018). Cryoprotective efficacy of local friesian bull's spermatozoa using tris-extender enriched with natural or synthetic antioxidants. Egyptian J. Anim. Prod., 55(1):1-6.

Izadia, F.; M. Jafarib; A. Asgarib and M. Salehib (2011). Protective role of N-acetyl-cysteine on diazinon induced oxidative stress in rat kidney. Clin Biochem, 44(13):S44

Jacyno, E.; A. Kolodziej; M. Kamyczek; M. Kawecka; K. Dziadek and A. Pietruszka (2007). Effect of Lcarnitine supplementation on boar semen quality. Acta Veterinaria Brno, 76: 595-600. 


\section{El-Nagar et al.}

Jannatifar, R.; K. Parivar; N. H. Roodbari and M. Hossein (2019). Effects of N-acetyl-cysteine supplementation on sperm quality, chromatin integrity and level of oxidative stress in infertile men. Reprod Biol Endocrinol, 17: 24.

Khan, A.; M. M. Yasinzai and M. A. Kakar (2015). Biochemical analysis of bovine (Boslndicus) seminal plasma. International journal of Advanced Biological and Biomedical Research, 3(4): 361-369.

Khan, A. A. (1994). Sexual behavior of the male camel (Camelus dromedaris) and some studies semen. M. Sc. Thesis, Bikaner Univ. Udaipur, India.

Kong, Y. I.; S. Zhou; A. J. Kihm; A. M. Katein and X. Yu (2004). Loss of hemoglobin stabilizing protein impairs erythropoiesis and exacerbates \$-thalassemia. J. Clin. Invest, 114: 1457-1466.

Koracevic, D.; G. Koracevic; V. Djordjevic; S. Andrejevic and V. Cosic (2001). Method for the measurement of antioxidant activity in human fluids. Journal of clinical pathology, 54(5): 356-361.

Lanzafame, F. M.; S. La Vignera; E. Vicari and A E. Calogero (2009). Oxidative stress and medical antioxidant treatment in male infertility. Reprod Biomed Online; 19:638-59.

Lasram, M. M.; A. J. Lamine; I. B. Douib; K. Bouzidb; A. Annabi; N. Belhadjhmida; M. Ahmed; S. El Fazaa; J. Abdelmoula and N. Gharbi (2014). Antioxidant and anti-inflammatory effects of Nacetylcysteine against malathion-induced liver damage and immunotoxicity in rats. Life Sci, 107(12):50-58.

Lenzi, A.; P. Sgrò; P. Salacone; D. Paoli; B. Gilio and F. Lombardo (2004). A placebo controlled doubleblind randomized trial of the use of combined 1-carnitine and 1-acetyl-carnitine treatment in men with asthenozoospermia. Fertil Steril, 81:1578-84.

Lenzi, A.; F. Lombardo; P. Sgro; P. Salacone; L. Caponecchia; F. Dondero and L. Gandini (2003). Use of carnitine therapy in selected cases of male factor infertility: A double-blind crossover trial. Fertil. Steril., 79: 292-300.

Matalliotakis, I.; Y. Koumantaki; A. Evageliou; G. Matalliotakis; A. Goumenou and E. Koumantakis (2000). L-Carnitine levels in the seminal plasma of fertile and infertile men: Correlation with sperm quality. Int. J. Fertil., 45: 236-240.

Mc Gowan, M. W.; J. D. Artiss; D. R. Strandoergh and B. Zak (1983). Aperoxidase-Coupled method for the colorimetric determination of serum triglycerides. Clin. Chem., 29: 538-542.

Michelizzi, V. N.; M. V. Dodson; Z. Pan; M. E. J. Amaral; J. J. Michal; D. J. Mclean; J. E. Womack and Z. Jiang (2010). Water Buffalo Genome Science Comes of Age. Int. J. Biol. Sci., 6 (4): 333-349.

Mora-Esteves, C. and D. Shin (2013). Nutrient supplementation: improving male fertility fourfold. Semin Reprod Med, 31:293-300.

Ng, C. M.; M. R. Blackman; C. Wang and R. S. Swerdloff (2004). The role of carnitine in the male reproductive system. Ann. N. Y. Acad. Sci., 1033: 177-188.

Petruska, P.; M. Capcarova and P. Sutovsky (2014). Antioxidant supplementation and purification of semen for improved artificial insemination in livestock species. Turk J Vet Anim Sci., 38: 643-652.

Rasul, Z.; M. Anzar; S. Jalali and N. Ahmad (1999). Effect of buffering systems on post-thaw motion characteristics, plasma membrane integrity and acrosomes morphology of buffalo spermatozoa. Animal Reprod. Sci., 59: 31.

Reitman, A. and S. Frankel (1957). Colorimetric method for the determination of serum glutamicoxaloacetic and glutamic-pyruvate transaminase. Amer. J. Clin. Path., 28: 56.

Richmond, W. (1973). Clin. Chem.., 19: 1350.

Safarinejad, M. R. and S. Safarinejad (2009). Efficacy of selenium and/or N-acetyl-cysteine for improving semen parameters in infertile men: a double-blind, placebo controlled, randomized study. J Urol., 181(2):741-751.

SPSS (2013). SPSS user Guide: Statistics SPSS.

Thundathil, J.; A. T. Palasz; A. D. Barth and R. J. Mapletoft (2001). The use of in vitro fertilization techniques to investigate the fertilizing ability of bovine sperm with proximal cytoplasmic droplets. Anim. Reprod. Sci., 65: 181-192. 
Tietz, N.W. (1990). Clinical guide to laboratory tests. 2nd ed. Philadelphia:WB Saunders.

Tietz, N.W. (1994). Fundamentals of Clinical Chemistry. 2nd ed. N.W. Tietz, editor, p 692.

Trinder, P. (1969). Determination of blood serum glucose. Ann. Clin. Biochem, 6:24.

Turkmen, R.; Y. O. Birdane; H. H. Demirel; H. Yavuz; M. Kabu and S. Ince (2019). Antioxidant and cytoprotective effects of $\mathrm{N}$-acetylcysteine against subchronic oral glyphosate-based herbicideinduced oxidative stress in rats

Vaz, F. M. and R. J. Wanders (2002). Carnitine biosynthesis in mammals. Biochem. J. 361:417-429.

Vicari, E. and A. E. Calogero (2001). Effects of treatment with carnitines in infertile patients with prostato-vesiculo-epididymitis. Hum Reprod 16(11): 2338-2342.

Wafa, W. M.; H. A. El-Nagar; A. A. Gabr and M. M. Rezk (2017). Impact of Dietary Moringa Oleifera Leaves Supplementation on Semen Characteristics, Oxidative Stress, Physiological Response and Blood Parameters of Heat Stressed Buffalo Bulls. J. Anim. and Poultry Prod., Mansoura Univ., Vol.8 (9): 367- 379.

Wahner, M.; M. Geyer; G. Hallfarth and U. Huhn (2004). The influence from additives of a vitamin emulsion with L-carnitine on the sperm qualities of AI-boars. Zuchtungskunde, 76: 196-207.

Walczak-Jedrzejowska, R.; J. K. Wolski and J. Slowikowska-Hilczer (2013). The role of oxidative stress and antioxidants in male fertility. Cen Euro J Urol 66(1): 60-67.

Wang, F.; L. Shourong; S. Yiqin; Z. Rangxiao; X. Jianjun; F. Hongying; P. Xuwan; S. Jingjing and C. Zhaobin (2014). Protective effects of $\mathrm{N}$-acetylcysteine on cisplatin-induced oxidative stress and DNA damage in HepG2 cells. Exp Ther Med 8, 1939-1945.

Yanagimachi, R. (1982). Requirements of extracellular calcium ions for various stages of fertilization and fertilization related phenomena in the hamster. Gamete Research, 5: $323-344$.

Zhai, W.; S. L. Neuman; M. A. Latour and P. Y. Hester (2007). The Effect of DietaryL-Carnitine on Semen Traits of White Leghorns. Poultry Science, 86(10):2228-35.
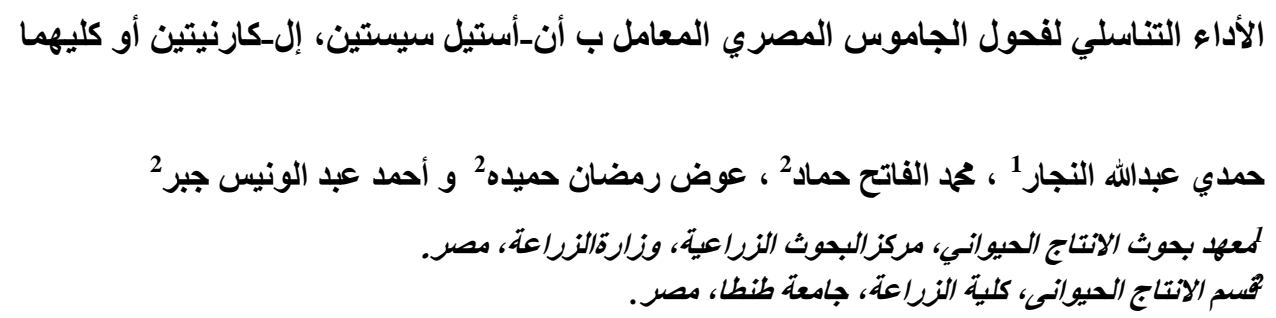

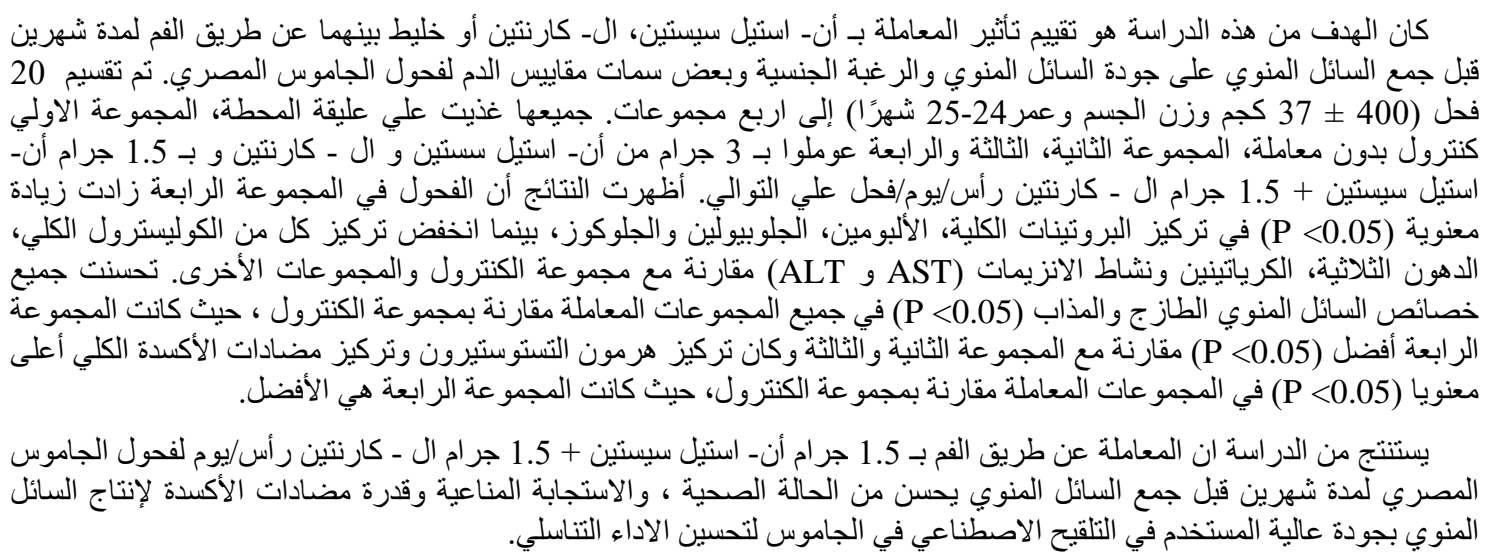

